\title{
From Pompeii to Paris: Ghostly Cityscapes and the Ruins of Modernity in Théophile Gautier and Eugène Atget
}

\author{
Alexandra Tranca \\ Trinity College, University of Cambridge, Cambridge, United Kingdom \\ Address: Trinity College, Cambridge CB2 1TQ, United Kingdom; \\ Telephone: +447588257418; \\ E-mail: iat24@cam.ac.uk
}

Alexandra Tranca is a third-year PhD student in French at the University of Cambridge, working on the relationship between ruins and the modern city in the Paris of the nineteenth century. Previous research explored the interactions between photography, the Pre-Raphaelites and Symbolism in relation to the spiritual. As a medievalist, she has worked on fantastical animals in Arthurian French literature, as well as art, vision and illusion in relation to chivalric ideology in the Roman de Perceforest, and modes of vision and divine knowledge in Dante's Earthly Paradise. She curated an exhibition on artists' books by Henri Maccheroni at the University Library, Cambridge, as part of the International Colloquium Les Espaces du Livre, Supports et acteurs de la création texte/image (20e-21e siècles) (Trinity College, 2013). Recently, she participated in the Symposium 'Zola au pluriel,' a collaboration between researchers from the University of Cambridge and L'Ecole Normale Supérieure (Cambridge and Paris, 2015). 


\section{From Pompeii to Paris: Ghostly Cityscapes and the Ruins of Modernity in Théophile Gautier and Eugène Atget ${ }^{i}$}

This paper explores visions of urbanity in the second half of the nineteenth century through Théophile Gautier's writings and Eugène Atget's photography, where the city appears depopulated, disembodied and haunted by the clutter of mundane urban furnishings. Viewed through the prism of a new discipline (archaeology) by Gautier and a new medium (photography) by Atget, ruined buildings, decaying streets, graffiti and enseignes, cart tracks and dingy storefronts configure an aesthetics of modernity. This aesthetics exploits the potential of the marginal, fragmentary and disjointed debris of modernity to define urbanity in the absence of the human element. The 'rags' and 'refuse' from which Benjamin would later construct his Arcades allow Gautier and Atget to articulate a creative tension between the fragments of historical layers, imbued with the memory of humanity, and their impact on the viewer. The deserted cityscape becomes a narrative strategy with epistemological and ontological implications in the spatiotemporal experience of urbanity: in this space, the banal, unintentional detail comes to articulate urban and/or modern identities.

Keywords Théophile Gautier, Eugène Atget, modernity, the urban 
Vous dites que nous sommes en progrès! - Si, demain, un volcan ouvrait sa gueule à Montmartre, et faisait à Paris un linceul de cendre et un tombeau de lave, comme fit autrefois le Vésuve à Stabia, à Pompéi et à Herculanum, et que, dans quelque mille ans, les antiquaires de ce temps-là fissent des fouilles et exhumassent le cadavre de la ville morte, dites quel monument serait resté debout pour témoigner de la splendeur de la grande enterrée, Notre-Dame la gothique ? [...] qui empêcherait de croire que Paris ne fût qu'un campement de Barbares, un village de Welches ou de Topinamboux, ce qu'on retirerait des fouilles serait quelque chose de bien curieux. Des briquets de gardes nationaux et des casques de sapeurs pompiers, des écus frappés d'un coin informe, voilà ce qu'on trouverait au lieu de ces belles armes, si curieusement ciselées, que le moyen âge laisse au fond de ses tours et de ses tombeaux en ruine, de ces médailles qui remplissent les vases étrusques et pavent les fondements de toutes les constructions romaines. Quant à nos misérables meubles de bois plaqué, à tous ces pauvres coffres si nus, si laids, si mesquins que l'on appelle commodes ou secrétaires, tous ces ustensiles informes et fragiles, j'espère que le temps en aurait assez pitié pour en détruire jusqu'au moindre vestige. ii

At midday the light is even, piercing through the darkness of narrow streets. A man alone stands propped against the wall on the sidewalk, close to an intersection. Two wooden boxes and a tripod lie at his side. He bides his time, allowing the details of the scene to sink in, while passersby trickle through in all directions. This is one of the old streets surviving in the Cité: it dates back to the mid-thirteenth century and its six centuries of history are still there mostly. It was only in the 1860s that Rue Boutebrie lost its head, cut by the Boulevard Saint-Germain, visible in the distance. The new boulevard took with it the odd-numbers buildings, a legendary hôtel, reputed the abode of the Reine Blanche, and the fourteenth-century theological college of Gervais Chrétien, canon of Paris. At $N^{\circ} 1$, though, the modern charitable dispensary still bears in an alcove the statue of St-Vincent de Paul, recalling that once the Little Sisters of St-Vincent de Paul had a house there; $\mathrm{N}^{\circ} 6$ proudly displays medieval gables, and $\mathrm{N}^{\circ} 8$ houses a rare example of sixteenth-century double-axis staircase, entirely in sculpted wood. iii Whether visible or invisible, inside or outside, these traces coexist with lively businesses. Vehicles of all descriptions crowd the street: carts, carriages, and wagons attending shop-fronts. Darkened by grime and time, the walls around overflow with scripts in all shapes and sizes. Shop-signs, posters, advertisements black with age and peeling, or new and bright, trumpet wares, services and shows: an enseigne beckons to Bois et Liqueurs and the publicity inscribed on the blind wall of the Rue des PrêtresSaint-Séverin advertises Service de verres et gobelets, the latest technological inventions, 
Automobile de France, and the current féerie, La Poudre de Perlinpinpin, on show at the Châtelet. In the affiches, the city constantly reinvents itself, promising commerce, industry, and culture in perpetual flux. Everything changes shape, from the street, whose cobblestones are dug out, to the collapsed and shapeless vehicle spilling various pieces onto the sidewalk. The man assembles a cumbersome view-camera out of one of the boxes and mounts it on the tripod, then covers it with a black cloth and ducks underneath. He manipulates the bellows shortening it to enlarge the frame; he adjusts the rear panel to acquire the desired focus and, satisfied, replaces it with a glass-plate negative. The photographer finally releases the shutter and light impresses the negative. The result would go down as Rue Boutebrie, Juillet 1899 (figure 1) in Eugène Atget's newly started series on Le Vieux Paris. In the intersection, the worker digging out the cobblestoned street has abandoned his task, distracted by two curious sights: the dismembered vehicle and the man with the antique camera contraption.

\section{Insert figure 1 here.}

Walter Benjamin and Carlo Ginzburg respectively offer 'rags' and 'refuse'iv and a 'conjectural paradigm'v as instruments to decipher the nineteenth century. A notable coincidence to be seen in these methods is that they are specifically applied to and drawn from the nineteenth century. Benjamin foregrounds discarded disjointed data and the ignored debris of history; vi Ginzburg argues for insights into an epochal ethos or event gained from marginal, incidental evidence, and cites the practices of various nineteenth-century figures, from Cuvier and Thomas Huxley to Sherlock Holmes. vii The impetus of constructing narratives exploiting the potential of discrete traces of everyday existence, of the contingent or idiosyncratic in material culture, of absences and discontinuities constitute methodological and epistemological approaches that both authors associate with modernity. In the nineteenth century, the epistemological value of details, fragments and traces reflects a cultural reality and determines the intellectual approach to cultural production, revealed in the fascination with ruins, archaeological missions and the antiquities craze; in the Naturalist penchant for l'effet du reel or the Parnassian and Symbolist cult for the isolated object. This attunement to a vestigial ethos appears in Théophile Gautier and Eugène Atget in relation to the affective processes that fragments stimulate in the context of urban experience, before and after Haussmann's reconfiguration of Paris. While expressing different attitudes towards the modern city, they both interrogate its texture of traces and fragments, and exploit the potential of contemporary furnishings to articulate urban space and ensure the survival of its identity. I wish to explore how literary and visual discourses engage with the (re)construction of Parisian urban space and spatial practices through the minutiae of daily life that seem to acquire a life of their own, transforming archaeology into an aesthetics of modernity and the inductive epistemological model into a creative force.

Ginzburg's 'conjectural paradigm' can be associated with the rising discipline of archaeology, which renewed the antiquarian ethos of collecting. This allowed for a creative tension between the fragmentary object and the totality it evokes. viii The phenomenon could be argued to direct the quest for knowledge vertically, across time, rather than space. Foucault would describe this reorientation as symptomatic of modernity, experienced as an acceleration of the pace of change and the crushing accumulation of time.ix In an urban context, this temporal anxiety develops in direct relation with 
which builds up to the Haussmannian intervention ${ }^{x}$ and its far-reaching echoes and reactions up to the end of the century. In the modern city, time-layers pile up vertiginously because space is constantly erased and re-written: demolitions, insurrections and conflagrations would make ruins of obscure streets and landmarks alike. But the city's face is also changed by the flow of fashions and goods, which, precisely because they are ephemeral, leave minute traces, accumulating imperceptibly on the city's streets. This allows for redefinitions of urbanity under the sign of commodities, while also questioning the survival of such an identity. In other words, what makes the modern city and what would survive it? '[I]nfinitesimal traces permit the comprehension of a deeper, otherwise unattainable reality: traces - more precisely, symptoms (in the case of Freud), clues (in the case of Sherlock Holmes), pictorial marks (in the case of Morelli).'xi Thomas Huxley calls this practice 'retrospective prophecy', based on Zadig's method. ${ }^{x i i}$ Drawn from a variety of disciplines, the epistemological model Ginzburg discusses is extremely versatile and can be seen at work in Gautier's explorations of urban configurations, and, with a different tenor, in Atget's representations of Paris. Common to both is the focus on the ordinary objects populating domestic and public spaces, and the traces they leave, as essential to reconstructing urban identity. However, they each differ in their attitude when undertaking an archaeological study of modern civilizations.

Writing in 1834 in the preface to Mademoiselle de Maupin, Gautier saw almost nothing of value in contemporary civilization's modes of expression: from furniture to briquet sabers and firemen's helmets, he seems to disparage their lack of an aesthetic dimension. The will to embellish everyday objects is absent, he suggests, by comparison to the medieval or ancient arms, artefacts, and architecture. The opening quotation illustrates how the author adopts and adapts an archaeological attitude to address contemporary concerns, from aesthetics and urbanity to modern comforts. It is noteworthy that, not constrained by scientific objectivity, Gautier's archaeology is shaped by at least three aspects: aesthetic considerations, culturally inherited antiquarianism, and the creative potential of the discipline's language and imagery. First, the aesthetic appears integral to his archaeological approach. For this reason, when he projects contemporary Paris into the past so that it may be studied and appraised by a future generation, he finds the present wanting. The Parisian examples, Notre-Dame and the Louvre's Ingres-decorated ceiling, illustrate the idea of artefacts as both functional and beautiful, despite Gautier's previously disassociating beauty from utility.xiii

Second, Gautier's archaeological conception is influenced by the environment out of which the discipline was developing: archaeology inherited the antiquarian tradition of collecting art and curiosités, attested by Balzac's contemporary evocation of the antiques shop in La Peau de chagrin (1831). From fine medieval arms to Egyptian funeral furnishings, Roman mosaics and Pompeian frescoes featuring in Gautier's writings, archaeology was uncovering and/or focusing on objects that were indeed spectacular; often aristocratic or royal possessions, in which utility and beauty were complementary. When they did not have intrinsic aesthetic qualities, Pompeian 'demandes de location, formules votives, annonces de toutes sortes' appeared 'curieuses comme le serait dans deux mille ans [...] un pan de mur de Paris, retrouvé avec ses affiches et ses placards.' xiv The short story Arria Marcella: Souvenir de Pompéi (1852) illustrates the process whereby time turns ordinary street furnishings into curiosities; their survival endows them with the aura of the extraordinary. This is the third consideration shaping Gautier's approach: archaeology is not a social science that recognizes the value of artefacts mundane and singular as a path to knowledge, contributing to the reconstruction of an age. Beyond such a scope, in Gautier's Romantic vision, archaeology supplies objects that incite and invite dreaming and creating a fantastic, desired past.

Among the first literary writers to embrace the aspirations of the archaeological 
approach, Gautier thus transforms it into an aesthetic mode. ${ }^{x v}$ His engagement with an imagined urban archaeology develops against the background of the city's anarchic development and the failed attempts to reorganize Paris, before Haussmann's intervention. ${ }^{\text {vi }}$ The Paris Gautier decries in Mademoiselle de Maupin is under the strain of industrialization, overpopulation, chaotic construction, and seemingly deteriorating living standards. By 1851, nothing appears to have changed, despite the efforts of successive prefects: ${ }^{\text {xvii }}$

Les trois quarts des rues ne sont que des ruisseaux de fange noire et fétide, comme au temps de la plus franche barbarie. Nulle trace d'art, nulle élégance, nul sentiment des lignes; des boîtes de plâtras percées de trous carrés, surmontées d'affreux tuyaux de tôle, voilà ce qu'on appelle des maisons au dix-neuvième siècle, dans une ville qui se prétend l'Athènes moderne, la reine de la civilisation!xviii

Gautier does not share the Paris physiognomists' delight in the heterogeneous cultures of the city; he sees the poor quality construction, the lack of comfort, of an urbanistic vision or architectural style; the ignorance regarding the importance of the aesthetic in everyday life. The disparaging characterisation of the 'quelques petits tas de plâtre' forming 'ruelles' lined by 'maisons bossues, chassieuses, rechignées, malsaines, contrefaites, couvertes de lèpres et de verrues, sans air, sans lumière, sans soleil, indignes d'être habitués par des lapins ou des porcs' emphasises his dissatisfaction. ${ }^{x i x}$ This leads him to indulge in an alternative urban and architectonic phantasmagoria: to edify a monumental French capital requires first 'passer sur le Paris actuel un rouleau qui écrase ses maisons et ses monuments, et en fasse un plateau parfaitement uni.'xx Refashioning Paris from scratch anticipates Haussmann's urban politics and illustrates a view opposed to that espoused by Atget, whose work on the same cramped, dark, dank streets and anonymous furnishings contributes to reinforce the aesthetic and ethical concept of Le Vieux Paris. xxi

If in Mademoiselle de Maupin or 'Paris futur', Gautier's archaeological imagination failed to find any redemptive trait in contemporary culture and civilization, he does not however forsake the modern city. His position is rendered complex by two related strands: first, the fascination with the value-enhancing patina of time and distance which he betrays in Arria Marcella and later in post-Commune Paris; second, the overwriting of ancient architectures onto modern urban spaces. These interests and practices reveal his exploration of the creative tension between modernity and change as rupture, on the one hand, and fragments of historical layers on the other. Exercises in prospective archaeology and the annihilation of Parisian civilization indicate a quest for a standard by which to identify and measure the contemporary city and culture. In the environment of the 1830s, when discourses of urban renovation ranged from the utilitarian to the utopic xxii and archaeology held the status of 'science of the future,'xxiii the projection of the present city into an envisaged antiquity provides a meditation on what could survive to define the modern identity of the urban. Subsequently, on the brink of Haussmannisation, Arria Marcella: Souvenir de Pompéi (1852) would ingeniously play out archaeology's promise to reveal 'something 'new' from the rubble of the past.'xxiv In this fantastic novella, a young man visiting Pompeii and deeply moved by the imprint of a woman's breast in volcanic ash succeeds in resuscitating the dead city and finding the woman whose beauty had been preserved by the fragment. Through the archaeological prism, Gautier will construe the modern urban ethos within a comparative frame, by constantly referring to ancient civilizations.

By comparison, Eugène Atget uses the archaeological viewpoint to construct an image of modernity with no other reference than itself: ${ }_{5}$ through the camera lens and the 
archaeologist's vision, pre-Haussmannian districts and mundane, marginal or ephemeral artefacts become historically and aesthetically charged objects. Half a century after Gautier wished for the obliteration of the material culture of his age in 1834, or imagined wiping out and rewriting the capital's geographical features and urban structure in 1851, Paris had passed through both forms of effacement and defacement. Labyrinthine, claustrophobic districts, decrepit medieval houses and hôtels were pierced by boulevards, hills were levelled and terraces raised according to need, during Haussmann's reorganization, while the Prussian bombardment and Commune fires later hailed ruin on Paris. From this end of the spectrum, the city that disappeared under pickaxes, shells and fire revealed a new fragility. Streets, buildings and the cultural products that embodied a way of life could no longer be taken for granted. By the time Atget took his photograph of Rue Boutebrie in 1899, every moment and aspect of the life of the old streets had become precious, as something that could be lost any time to programmed or accidental destructions. This is why he set out to map Le Vieux Paris, building a visual archive until his death in 1927.

Depicting the urban landscape through deserted, medieval narrow streets, through walls plastered with advertisements, spilling out old clothes and furniture or revealing once-majestic façades, the photographer conveys the fragility and sense of loss of a changing city and culture. The shops and businesses in Atget's images had long been established there, as shown for example in Charles Marville's photographs of rue Boutebrie. ${ }^{x x v}$ Their diversity was a characteristic of the street according to Charles Lefeuve's guide, but their survival was no longer certain.xxvi Aware of these aspects, Atget renders the patina of time to the featured businesses, contributing to the street's picturesque quality. Similarly, posters advertised shows that had been around since the 1840s and the photographer seems to play out this vintage quality when he uses La Poudre de Perlinpinpin in his composition for Rue Boutebrie. The féerie had been expanded and modernized for the re-opening of the Châtelet Theatre in 1898. xxvii Although alive and thriving in 1899, the street and its furnishings could also be characterized as antique and picturesque, thus acquiring the status of a curiosité in the photograph. The choice of what to include in his composition thus appears deliberate, conscious that it sought to capture a mood and create an effect. The result is a 'coin pittoresque' in Paris, but here new and old aspects are conceived in fact as already-ancient strata, enveloped in an atmosphere of mystery and nostalgia, close to that experienced before ancient vestiges. Springing from a different sensibility, Atget's project also draws on an archaeological ethos that, albeit closer to the scientific dimension, ultimately produces another kind of fiction: the myth of Le Vieux Paris.

Similar questions to those raised by Gautier's experiments animate Atget's quest to capture the essence of the city and contemporary Parisian civilization. The awareness that had been growing of the city's transience and the need to preserve its memory, if not its topographical imprint, led to photography's active role in patrimonial conservation. Didactic and meticulous like Gautier, Atget conceives of himself as a collector and of his photographic project as an archival enterprise, documentary and not artistic. Nonetheless, series like Art dans le vieux Paris would earn him the status of pioneer of modern photography and inspire the Surrealists. xxviii Despite rejecting the aesthetic dimension, Atget's photography functions within the same mode of archaeology as an aesthetics of modernity. The documentary recording of old streets is marked by a subjective, singular vision, where space is played out as a tension between emptiness and overcrowding. The first feature is forcefully present as Atget's streets are conspicuously deserted, except for the occasional blurry human shape: winding strips of cobblestones or leaning walls framing emptiness articulate the urban. The images' crowded quality, on the other hand, emerges with the same irregular walls impinging on the viewer's space, narrowing the space tunnel-like to create an intimate view of the street's topography. The populous atmosphere also derives from the 
contemporaneous urban-scene décor, from enseignes and affiches to vehicles and wares, often pictured as an overflowing abundance.

Gautier's prospective archaeology of Paris tipped the scales in favour of the accomplishments of ancient civilizations. Conversely, standing on the other side of Haussmann's urban revolution, in the aftermath of the Franco-Prussian war and the Commune, Atget's project to capture Old Paris marries the archaeological approach with a Decadent influence and a Baudelairian sensibility towards modern urban culture. His archaeological project of Paris would seem more in accord with scientific rigour, registering urban realities indiscriminately. Thus, he would photograph a street valuable for its architecture or history, as accompanying notes attest, ${ }^{\text {xxix }}$ but also take in its modern transformations, be they new buildings, merchandise, advertisements, rubble etc., unlike contemporary photographers. ${ }^{\mathrm{xxx}}$ As argued above, the resulting composition is no longer simply a historic document of archaeological value. The same fragility Gautier had denounced in modern furnishings is valorized in a manner reminiscent of Baudelaire: the ephemeral quality of things not made to endure, but to be used, consumed. Additionally, Atget capitalizes on an aesthetic of ugliness through the exploitation of prosaic urban elements, such as dingy shops and carts, exploring their potential to reveal the eternal in transience, fragmentation and bizarre details. xxxi Paying attention to both the historically or aesthetically valuable and humble, perishable objects, the images produce unexpected juxtapositions. As in Baudelaire's 'Le Soleil', which enters 'dans tous les hôpitaux et dans tous les palais' (1.20), in Atget's photographs, the sun shines evenly on peeling adverts and Renaissance residences alike.

Whatever his aesthetic and architectural tastes, Classical and monumental, respectively, Gautier too is receptive towards quotidian details, insisting on their role as markers of the city's character, shaping its identity. Atget's avoiding the monuments and newly-created postcard sights of Paris curiously resonates with Gautier's professed interests in 'Une Journée à Londres' (1844):

ces petits détails sans doute fort mesquins aux amateurs de dissertations esthétiques, aux admirateurs jurés de monuments [...] c'est tout cela qui constitue la différence d'un peuple à un autre, qui fait qu'on est à Londres et non pas à Paris. ${ }^{x x x i i}$

Still, to what extent do such pedestrian features define the city? In an era bursting with the epistemological energy of the concrete and objective that confirms reality, 'le detail inutile' participates in creating l'effet du réel in narrative discourse.xxxii It does not signify, but it authenticates. What would happen though if this in-significant detail would come to signify the city? Produced before and after the Second Empire's urban restructuring, Gautier's and Atget's works perceive the city differently. Yet both authors, I argue, have in common the topos of the deserted cityscape as a narrative strategy with epistemological and ontological implications in the spatiotemporal experience of urbanity: in this space, the mundane, unintentional detail takes centre-stage to articulate urban identities.

First, by focusing on the evocation of spaces devoid of human presence, but marked by the traces of their passage, the authors construct an image of the city as somehow disembodied, on the threshold of reality or suspended between life and death. In the context of modernity, the abandoned city seems a paradox, but it can be construed as an extreme depiction of the transience of the modern. Disembodied urbanity is a recurrent motif in both authors, with a 
difference though. Atget restricts his album to Paris streets; conversely, Gautier's other empty cities, such as London, in 'Une journée à Londres' or Pompeii, in Arria Marcella, contain Paris inscribed en filigrane. Constant comparisons with Paris add another ghostly dimension to the deserted sites, as if a city in the negative loomed behind the actual places described.xxxiv Moreover, at a time when the city's pulse is measured in the vigour of the crowd flowing through its streets, the choice to exclude the human element bespeaks an archaeological approach, as if both Gautier and Atget were undertaking a post-mortem analysis of the urban subject, attempting to locate traces of its spirit in the material remains.

This can suggest that the modern is so fleeting that it can only be grasped retrospectively, once it has spent itself utterly. From this perspective, the absent citizens belong to a post-cataclysmic scenario, which opens up the space for the contemplation of modernity, brought to a standstill. The quiet clash between the usual noise of a peopled city and the silent objects inhabiting its streets are reminiscent of Benjamin's dialectical image. ${ }^{\mathrm{xxx}}$ This image has an epiphanic quality, offering a disruptive, non-progressive vision that articulates the unreconciled tensions of modernity: xxxvi here, the material oversaturation in the disembodied and motionless city reveals modernity's flux as a performance.xxxvii This means that the proliferation of objects displaces, replays and replicates the present which defines modernity's mode of existence. ${ }^{x x x v i i i}$ In these literary and photographic representations of the empty city, the implications of the performance revealed by the dialectical image do not necessarily concern a collective awakening to historical truth about the consumer society. My use of the dialectical image remains grounded in its literary and photographic sources. Rather than transferring it to

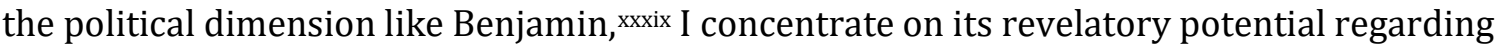
aspects of aesthetics and cultural production. The discontinuity between the present and the past it touches, which Benjamin describes at work in the dialectical image, illuminates the rupture modernity enacts between representation and its external referents. Therefore, whether commodities, imprints, or scripts, these objects cease to belong to social or cultural reality and become ghostlike characters or signs enacting, or writing a surreal palimpsestic space.

The palimpsest's conceptual richness is apt to characterize the operations performed onto the urban fabric by Gautier and Atget. For instance, the evocation of urban furnishings may be perceived as erasing their immediate purpose (documenting) and replacing it with autonomous aesthetic and/or narrative content: in Rue Boutebrie, one third of the composition is made up by the collage of posters adorning the blind wall at the end of the Rue des PrêtresSaint-Séverin. The different printed fonts, the shapes and sizes of the frames in which the advertisements unfold their message constitute variations in the rhythm and texture of the street; just as the houses vary in dimension and manage their façade spaces differently - the disposition of window-frames, division of shop-fronts. Freed from their significance, the realistic, minute data in these fictional archaeologies feed a fantastic construct, whether Gautier's resurrected Pompeii, fossilized London on Sunday or Atget's Parisian counterpart. Benjamin's tenet concerning the dialectical image, that 'for a part of the past to be touched by the present instant there must be no continuity between them', is realized in Gautier's and Atget's narratives, as I suggest below, through heterotopic discourses. ${ }^{\mathrm{xl}}$

The conundrum of a city with no people, yet breathing with all the signs of daily activities, may be read through Foucault's concept of hétérotopie, defined as a concrete space inhabited by the imaginary, reflecting an image of the place in the negative.xli In Atget's and Gautier's cities, the heterotopia concomitantly affirms and contradicts urban realities: the usual relationships are in place and occupy designated spaces, but in such a way as to negate them. This is translated as the tension between objects that poignantly indicate busyness and business, and the conspicuous lack of human animation. Atget's Rue des Prêtres-Saint-Séverin (1898) 
(figure 2) and Angle de la rue Laplace et de la rue de la Montagne-Sainte-Geneviève (1898) (figure 3) exemplify Benjamin's dialectical image and Foucault's hétérotopie d'illusion, xlii staging and, respectively, exposing the real bustling street through a distorted, illusory image. In both images, chaotic objects suggest an expenditure of human energy, in contrast to the silence of the empty street.

\section{Insert figure 2 here}

In Rue des Prêtres-Saint-Séverin from the run-down shop of the Brocanteur, fabrics and garments sprawl onto the sidewalk, hanging from the walls, piling on furniture in the street, along with an odd assortment of utensils and a sewing-machine table. In Rue de la MontagneSainte-Geneviève, the close-up highlights the intense activity, expressed as an overabundance of commodities. In antithesis to Zola's Au Bonheur des Dames, there is no effort to master this flow of goods here. The objects' overflow is emphasized through the intersection, superposition and juxtaposition of shop-signs, advertisements and merchandise: the open-book sign advertises Lecture in the foreground; below, toys complement the press, while on the corner the F.Morlé grocery vies for attention with the sign above, 'Ancienne maison Audois, fruits et primeurs, salaisons d'Auvergne, Chocolat Vinay.' This image's title and composition epitomize the essence of the street as a mosaic of scripts crisscrossing frantically, crowding and jostling, just like the usual throngs circulating. What could reveal though an hétérotopie where commodities inhabit the streets excessively, ousting the population?

\section{Insert figure 3 here}

Benjamin's dialectical image takes the form of a palimpsest, as an expression of modernity's autonomy of representation of history, urbanism or aesthetic bodies. As autonomous discourses, Gautier's writing and Atget's photography challenge the restriction that 'since the different epochs of the past are not all touched in the same degree by the present day of the historian (and often the recent past is not touched at all; the present fails to 'do it justice'), continuity in the presentation of history is unattainable. 'xliii Continuity is subverted but that is not because either Gautier or Atget fails to engage with the recent past. On the contrary, the photographer's work is entirely devoted to the recent past and still-present Paris, while Gautier engages the history of the city's urban development into modernity and future. The recognisability that a dialectical image would effect in this case is that the past is neither a linear nor a singular narrative, but rather a stage to be revisited, allowing again and again for new plays to be set there, as the empty, dramatic décor of Atget's streets suggests. Its props, whether ancient cart tracks and inscriptions in Pompeii or merchandise and posters in modern Paris become available to take on different roles in each reader, viewer or character's narrative. I will return to discuss the autonomy of such objects in the two authors' visions at a later stage.

Abandoned, mingling chaotically, the objects bespeak a state of loss, mimicking absent human agency. Thus, although unpopulated, the street is not uninhabited, creating a disturbing feeling. This is similar to what Gautier's hero experiences in ruined Pompeii, a multi-layered hétérotopie where he confronts the surprisingly familiar sight of

ces inscriptions tracées en lettres rouges, d'un pinceau cursif, sur les parois des murailles: affiches de spectacle, demandes de location, formules votives, enseignes, annonces de toutes sortes [...] xliv 
Atget's gesture of emptying the city of people petrifies it into a vestige, like Pompeii; inversely, Gautier's inscriptions bring the dead city closer to the living modern metropolis. Foucault's heterotopias of space and time inform the rewriting of Paris as a Pompeii, fossilizing modernity into a haunted object-filled world in Atget.xlv By contrast, Gautier overwrites Paris on Pompeii by comparing the shared concerns that animate modern citizens in the capital and the inhabitants of a provincial Roman town nineteen centuries before. Advertisements and their content indicate identical modes of expression, thus creating a strange mixture of kinship and alienation, close to Freud's uncanny. By reducing temporal and cultural distance, the space can be appropriated as familiar in Gautier; in antithesis, Atget's photographs transform the known Paris into an alien environment. Separating the inhabitants from the street, from scripts and objects that address them familiarly, Atget subverts the possibility of communication since there is no recipient. By comparison, Gautier's characters substituted themselves to the ancient Pompeians, reacting to the stimuli of their Roman-city environment. However, in both cases this new-found closeness generates unsettling feelings, since the very mundane, essentially impersonal details of urban spaces are revealed instead to be very personal, speaking of the needs, desires and fears of real people who interact with such scripts. As snippets of real lives, they are also clues that feed the desire to know more, to reconstitute the story. Such a longing would imply becoming more intimately connected with a dead, alien space, but where the objects still speak.

On Atget's streets, adorned with seemingly abandoned prosaic conveyances and whose walls are tapestried with the same (peeling) advertisements from Gautier's Pompeii, mundane objects can still exercise fascination and hold secrets, precisely because of the fragile, ephemeral quality which imbues them. Like the cart-tracks and graffiti still visible in Pompeian streets, the newly dug-up hole in the pavement of Rue Boutebrie or parked tricycle outside the Cycles shop in Porte du Dragon, rue de Rennes (1899) (figure 4) inspire the sentiment of a profoundly contemporaneous experience contaminated by a sense of urgency suspended, of fleeting gestures and actions arrested. Here, effet-du-réel details construe the spatial discourse, so that they unwittingly acquire a semantic dimension, promising to signify. As in Octavien's experience of the Pompeian graffiti, in Atget, the trivial and disjointed debris of urban furnishings prove to encode feelings and excite an affective reaction from those interacting with them, whether visitors of Pompeii or viewers of Paris images.

The Arria Marcella passage explicitly parallels the Pompeian street-décor with a Parisian sample that future archaeologists could discover, commenting on the 'curious' experience this would make. xlvi The term alludes to the transformation of the familiar into the unknown: divorced from their referential frame, objects loose meaning and become susceptible to emerge in unexpected situations. Back in 1834, when he transposed Vesuvius onto Montmartre, Gautier predicted that the contemporary urban products furnishing private and public spaces would fall short of the cultural refinement of bygone ages and defunct civilizations. Rather, misguided ideas of progress through industrialization, resulting in anarchic urban expansion and a pernicious penchant for the utilitarian, set Paris on a par with Barbarian and indigenous settlements. Gautier lamented the aesthetic sacrificed to exacerbate the functional and the prosaism of contemporary impersonal artefacts, inferring that, instead of comfort and protection, the utilitarian spells disfigurement and anonymity for the city and its objects. Such an impersonal urban experience leaves no room for gratuitous beauty, 'entre les ceintures élastiques, les cols en crinoline, les biberons en tétine incorruptible, la pâte de Regnault et les recettes contre le mal de dents. 'xlvii Here, the same epithet 'curieux' was used pejoratively to infer that the carcass of the dead city would bear an uninspiring imprint, denoting spiritual poverty, rather than the effervescence of creating beautiful artefacts. 
Atget's photographs seem to test this hypothesis in an experiment that enacts an hétérotopie d'illusion, by projecting a Paris subjected to the fate of Pompeii. The vision is not without echoes of the 1870-1871 destructions, often perceived as the result of the Second Empire's excess and decadence, which was itself associated with the Latin decadence. Notably, Gautier himself had described Paris as a new Pompeii, walking in its ruins, in 1871. xlviii For the narrator, experiencing a previously known city in its ruinous incarnation meant undertaking an oneiric flânerie across an unreal, unfamiliar and bizarre landscape. Moreover, this stance would illustrate a different contemporary meaning of 'curieux': the attitude of an enlightened connaisseur who 's'occupe de tous les monuments de l'activité humaine' with an eye for discovering their beauty; ${ }^{\text {xlix }}$ the narrator's appreciation of the aesthetic effects of fire and petroleum supports this position. Atget's treatment of the objects is closer to this vision of the 'curieux' observer. His still-life representation of Paris seeks to capture and excite in viewers the sense of curiosity that would be experienced by someone for whom the city appeared as exotic as Pompeii.

By accentuating the orthogonal planes in Angle de la rue Laplace and Rue Boutebrie, and avoiding a frontal view, Atget creates depth and the impression of a privileged position affording a far-reaching and intimate perception of space. Spying out the street's secrets with the casual air of the flâneur allows for narrative potential, as spatial depth translates into time. But such expectations are simultaneously rewarded and thwarted, because carts and merchandise point beyond themselves to absent owners and purveyors, without, however, losing their materiality or literal, prosaic nature to become allegories. Instead, by offering themselves to the gaze, they tease through their familiarity, while preserving the disturbing ambiguity as to the ghostly presences that shadow them: will their owners come, are they there or have they gone and, if so, where, when, why? Unlike in Arria Marcella, in the still Porte du Dragon the longing to know is not alleviated by the knowledge that some cataclysmic event has wiped out the population of Paris.

\section{Insert figure 4 here}

Still, if wine bottles in window-shops, children's play-balls, firemen's helmets and assorted signs and notifications are the only remnants to speak of urban culture, such marginal details suddenly acquire an epistemological dimension that raises the question of individuality in modern (urban) culture. Raised to more-than-ordinary status, the discarded objects remain anonymous, rather than preserving the singular trace of an individual, like the imprint of the breast in Arria Marcella. Nevertheless, equally enveloped in the mystery of their survival and because of their generic quality, they open up the city to receive the personal imprint of the beholder, the only certain presence in this landscape. The intrigued gaze picks out the curves of streets and buildings, the diffuse light and arbitrary preservation of ephemeral traces of the ordinary that make up the existence of an unassuming street; the imagination conjectures on the possible lives of the city.

The focus on the mute discourse of objects creates the space for writing a personal narrative, a personal heterotopia. ${ }^{1}$ This is what Octavien does in the ruins of Pompeii, what Gautier and Atget challenge readers and viewers to do with the potential ruins of Paris and within its narrow, winding streets. Except that in Gautier's story, the hero's desire resuscitates Pompeii, repopulating its streets, and thus turning into reality the archaeological suppositions, while Atget's archaeology depopulates Paris, rendering it haunted, oneiric and unreal. Although inverse gestures, both discourses turn urban spaces into open-ended stories, for example, with Pompeii lending itself to Octavien's overwriting in an hétérotopie de compensation. ${ }^{\mathrm{li}}$ In the short story, overtones of contemporary urbanity

emerge and are corrected through critical 
comparisons: for example, in contrast with the lugubrious cemetery, another heterotopic instance, ${ }^{\text {lii }}$ the sanitized tomb-bordered road excites 'une curiosité allègre et une joyeuse plénitude d'existence.'liii The description would not be misplaced if it referred to a flâneur enjoying the life of the city. In Pompeii, this space displaces the stillness of death: aestheticized, abstract, it becomes a celebration of life. Drawing together the modern and the ancient, the narrative prepares Octavien's transfer into the compensatory heterotopia.

Unable to find fulfilment in his own spatiotemporal continuum, Octavien projects his aspirations onto a real space, 'une ville détruite avec ses habitants disparus, 'liv over which he inscribes a past (imagined) time-frame. Illustrating Foucault's concept, heterotopic Pompeii is both real and illusory. Significantly, it achieves this state by making the inconspicuous traces of mundane circulation a driving force, turning the wheel of time:

la roue du temps était sortie de son ornière, et son désir vainqueur choisissait sa place parmi les siècles écoulés! Il se trouvait face à face avec sa chimère, [...] une chimère rétrospective. Sa vie se remplissait d'un seul coup.lv

The temporal ornière evokes the 'ornières de char creusées dans le pavage cyclopéen des rues' which Octavien observed 'd'un œil effaré' during daytime. lvi Their eloquence incites a desire so powerful that it alters space and time.

Gautier's Pompeii may have discovered how to bring modernity to a standstill, by reflecting modern spatial practices in ancient ones. His narrative technique plays out the constant overwriting of ancient and modern, through juxtaposition and comparison. For instance, it is by train, epitome of modernity as movement and speed, that the characters in Arria Marcella reach the dead city. The narrator registers the incongruous association evoked by the syntagm 'Station de Pompéi', a temporal oxymoron, whose mutually anachronic terms indicate the characters' entrance in a heterotopic space. The glaring hyperclarity of the meridional air and light create an oneiric atmosphere, as the narrator further remarks, lvii hence recalling the heightening of sensorial perception in dreams. Likewise, the mist obscuring parts of the landscape reinforces the dream-impression. The space thus rendered unreal by nature and technology makes the city concomitantly 'ressuscitée' and ruinous. Assuming this in-between state of expectation, Pompeii's space offers itself to Octavien's palimpsestic performance.

Gautier's and Atget's urban experiments foreground inverse operations of each other: a dead ancient Pompeii reanimated and a modern Paris fossilized. Each becomes a liminal space, at once real, documenting streets with their specific features and occupations, and unreal, a reflection showing a dead city where the viewer/reader knows it to be alive or quite the reverse. The ensuing heterotopias appear as palimpsests that disturb both space and time. In Atget, objects become events in Rue du Grenier-sur-l'eau (1900) (figure 5) or actions in Rue Boutebrie: one is under demolition; in the other, the hole in the pavement is signposted because work is in progress. The scene is strongly reminiscent of the Pompeian streets with their 'ornières de char creusées dans le pavage cyclopéen des rues,' the 'forum surpris au milieu d'une réparation [...] et dont les colonnes, les architraves toutes taillées, toutes sculptées, attendent [...] qu'on les mette en place,' the 'boutiques où ne manque que le marchand.' 'viii All these objects attest that the street is 'in business,' but in this dimension, they are the performers, as the verbs suggest: 'les architraves [...] attendent.' Still, active expectancy only renders this loss more acute, enticing the visitor or spectator to long to restore the humanity to the urban space. An 'œil effaré' takes in these details en flânant Pompeii's empty streets. In the photograph, however, the visual dynamics emerge through the slanting angle 
corroborates the material evidence and undermines it by emphasizing the absence of human agency. Thus, common to both discourses is how incidental indicators become the inanimate agents and performative entities in an alternate urban space, generated within a temporal dimension outside of time.

\section{Insert figure 5 here}

The relation between time and agency is worth exploring further, as the space and vision of the deserted city provoke temporal complications, entering the realm of hétérochronies. ${ }^{\text {.ix }}$ Spatial displacement is associated with temporal deviation in Gautier's 'Une journée à Londres.' Through palimpsestic strategies, the consistent comparison of the monumental edifices in industrial London districts with the colossal architecture of ancient civilizations superinscribes onto the modern city a contradictory temporality:

une forêt de cheminées colossales, en forme de tours, de colonnes, de pylônes, d'obélisques, donnait à l'horizon un air égyptien, un vague, profil de Thèbes, de Babylone, de ville anté-diluvienne. ${ }^{\mathrm{lx}}$

Towers, columns and obelisks conflate several simultaneous space-time continuums projecting onto nineteenth-century London an Egyptian-Theban-Babylonian quality of the cyclopean, excessive antediluvian world. Despite symbolizing an overwhelming, titanic energy and superhuman efforts, the gigantic works of now-dead cities extend their immutable sculptural quality to petrify human activity in the city. This atmosphere is close to that of Rue des PrêtresSaint-Séverin, where a deserted second plane suggests that emptiness reverberates further into space, while movement is stopped dead in its tracks, contradicting the visual concentration of garments, tools and furniture outside the shop, which would convey the dynamism of exchanges.

Instead of animation, silence, stillness and emptiness populate the streets, just as, in Porte du dragon, no one passes under the archway, enters the shop that sells Cycles, or stops at the restaurant opposite. 'La vie semble être suspendue' and time itself stopped, observes Gautier. ${ }^{\text {lxi }}$ Echoing the processes at work in Rue Boutebrie, Gautier's descriptions highlight the contrast between London's metamorphic nature, as a space in constant movement, changing and exchanging ('ville navale'), and the frozen, Sunday-closed public places. The paradoxical state of the city on Sunday creates a heterotopic London through distorting hétérochronies. The shocking disruption of life reveals the danger of running out of humanity through objectual démesure. Without the human element, urban spatial markers become the performative entities in a chronotope whose expression is fossilized, monumental time or the time experienced in legends, dreams and the Otherworld. The dramatic quality of such images suggests a sort of still-life performance, or a scene in the spirit of Piranese, Monsù Désiderio and John Martin, anticipating the Surrealist landscapes.

Despite the professedly archival scope of his photography, Atget's urban landscapes are not simply objective reproductions. Their compositional choices and subject matter proceed to distort, conflate and cancel out time altogether, constructing a mirroring, non-temporal dimension. Building on Barthes' observations of time-processes in photography and associating them with similar conditions affecting the ruin, it can be argued that textual and visual discourses articulate the recognition of the past in present experience, as if the present is already past. A Benjaminian reading would emphasize this as the state of modernity, glimpsed fleetingly even as it disappears, transformed. The space articulated in the image allowing temporal confusion or deliberately provoking ${ }_{13}$ it is a condition that can be associated with the 
many temporalities that Barthes identifies in photography and that can be encountered in mythical or imaginary geographies. Rue du Grenier-sur-l'eau, for example, provides a complex temporal experience by conflating the present of the spectator's time, the time when the picture was taken, during the street's transformation, and the time-frame occupied by the space and objects in the picture, which reach even further back into the past. lxii

However, neither viewing one of Atget's streets or walking in Pompeii operates merely as a time machine. ${ }^{\text {Ixii I }}$ In the space of both narrative and image, time does not enter just a different continuum. Instead, it amasses different time-scales and suspends them in a no-time. As in the Neapolitan museum, with its preserved fragments from different epochs and places (another Foucauldian heterotopia), Octavien's Pompeian adventure mingles the accelerated time of railways and the petrified time of first-century cart-tracks; or the constraining street-fashion of nineteenth-century Paris and the nonchalant Roman garb. Furthermore, night and day converge producing a time outside of time, where the ruined city is whole and Octavien moves within the time-frame of ordinary daily occurrences.

From a different perspective, the train from Naples to Pompeii may be associated with a psychopomp vehicle transporting the hero between states of consciousness or ontological statuses, for instance, allowing him to travel back and forth between reality, dream and death. Nevertheless, these existential conditions interact in an unexpected manner with space: in reality, daytime Pompeii is a dead, ruined city; during Octavien's night-time walk, it appears as a dream landscape, a crepuscular half-restored, partially-defined space, inhabited by shadowy presences. Finally, in what would be the death state, the hero experiences a city restored and alive. Yet the resurrected Arria's return to ashes at the climactic point and the hero's impossibility to reach a satisfactory dénouement ultimately infer that this heterotopia built by desire cannot acquire temporal depth. Octavien's sculptural aesthetic ideals hint at the fact that such a desire is oriented towards fixity. Thus, the heterotopic image of Pompeii likewise contradicts the idea of life unfolding in time: for the imprint of Arria Marcella's breast, a fragment displaced in the present, Octavien creates a disrupted time superimposed over the fragmentary space of Pompeii, fixated in its ideal state.

Gautier's predilection for immobility is comparable to how Atget achieves something like stable time by removing the actors from the scene, so that their imprint in space becomes atemporal. What emerges is an impression of the city that mirrors its actual existence, but in a distorting reflection, where the petrified present becomes the object of an urban archaeology. In its photographic representation, the space of the street is no longer subject to time's immediate pressure, while preserving the different temporal layers and planes (street repair, peeling advertisements). In this sense, Atget's Paris is also illustrative of the hétérotopie d'illusion and hétérotopie de compensation. His illusion of the deserted city creates the conditions permitting the preservation of the memory of heterogeneous (popular) cultures and the character of particular streets then perceived as threatened by extinction. Crowding in the empty space of the narrow, curving streets, as in Angle de la rue Laplace, the multitude of merchandise, ephemera and immobile markers of urban space compensates for the disappearance of the human population. The traces of the 'transitory things that people do and are have washed away, leaving only their transcendent accomplishments.' Ixiv The illumination that a ghost-city Paris would perform in this case is not necessarily in the direction of historical revelation to which Benjamin would allude. ${ }^{\mathrm{lxv}}$ Yet the past can still appear as a flashing image by discovering and restoring the meaningfulness of the (apparently) empty time that fills ordinary daily movements, from street works and dismantling vehicles in Rue Boutebrie, to demolitions that alter urban topography and scripts that cover and uncover the buildings' surfaces in Rue $d u$ Grenier-sur-l'eau. In Atget's photography, 
ethos of their culture, making the empty time that fills ordinary daily movements become meaningful. Viewers invest the past with their present by recognising in such small traces and occurrences the City at a particular moment in its life.

Envisioning urbanity in the 'antiquity'-mode could then be conceived a 'necessary consequence of modernity,' allowing for the study of its processes. ${ }^{\text {lxvi }}$ Projecting the present city into an envisaged antiquity posits at once a re-appropriation of, and distancing from, it whereby can be construed the memory of the urban space, whether this is Pompeii, Paris or London. In this light, the 'anterior future tense' which constitutes the temporal frame in photography appears curiously suited to 'fix the disappearing past and the fast-developing present.' Ixvii Photography can acquire the value of archaeological vestige, imprinting the past within its shallow surface, just as the volcanic ash preserves the imprint of Arria's breast. Yet it can also constitute a form of externalised memory, the sensitized photographic plate marked by the viewer's experience, bearing their souvenir, just as Gautier's text registers Octavien's experience of ancient urbanity.

Such considerations are reflected by Atget's project, which addressed a contemporaneous audience, aware of being about to lose certain parts of their city to the planned renovations at the turn of the century. Time-layered spaces would disappear to privilege a new spatial concept, playing on surface regularity, rather than temporal nooks and crannies. From the loading and unloading of carts and street-works to poster-and-advert strata, obscure culs-de-sac and decrepit buildings full of history, photographs register lost time (and space here), which cannot be recuperated, but whose loss is thus documented and remembered. Ixviii The photographic document does not stop the passage of time. Instead, it prolongs the past's existence 'in another dimension, between site and sight,' in some cases becoming the sole vestige of that past space's identity. Ixix This is the case of the dégagement in Rue des Prêtres-Saint-Séverin or Rue du Grenier-sur-l'eau, ephemeral ruins recording the latter's metamorphosis. As fragmentary documents, the experience of the past that photographs offer engages at different levels with the idea of authenticity. For Atget's contemporaneous audience, his photographs are unique traces of a vanished space and fleeting moment; despite being selective constructs of time and space, they are perceived as authentic witnesses. ${ }^{1 x x}$ In addition, for present-day viewers, they are material objects and the only survivors of a lost world, thus functioning like ruins. Anchoring the past as authentic fragmentary vestiges, visible and tactile presences, they reclaim their own and the past's authenticity. Gautier's novella operates similarly: its subtitle, Souvenir of Pompeii, indicates that the text is a memorial vestige, much like the photograph. Moreover, again, for the present-day audience, the narrative preserves a space and traces that no longer survive in the ruins of Pompeii, including the crucial breast-imprint that fascinated Octavien. Gautier thus preserves the human ruin in his vestigial text.

Between elusive space and human and material oversaturation, the sprawling city becomes a flickering image. Narrative and photography effect the renovation of urban modernity through the street-level exploration of surfaces, from cart-tracks to peeling advertisements, allowing traces and layers to dilate time into new spaces, which become the loci of new, palimpsestic performances. Like Pompeii's ruinous architecture and London's phantasmagorical edifices, Paris photographs engage a diachronic interpretation of space, conflating the strata of the past, from creation to destruction and appropriation. ${ }^{\text {xxi }}$ From the documentary to the fantastic, attempts to map out and preserve disappearing aspects of the cityscape construct surreal spaces of deserted streets or reanimated ruins in an out-of-time continuum, where objects act out the life of the city. The contrast between the objects' material presence and the ghostly traces of human passage builds an uncanny realm in which visions of modernity unfold while remaining suspended. Despite their diverse approaches, both Gautier 
and Atget adopt the contemporary topos of the disappearing city and explore post-apocalyptic visions to articulate urban identity as essentially fragmented, fragile and displaced, motifs which will be taken up by the Surrealists, for instance, in Giorgio de Chirico's Le chant d'amour (1914). 
${ }^{\mathrm{i}}$ My title makes reference to Goran Blix, From Paris to Pompeii. French Romanticism and the Cultural Politics of Archaeology (Philadelphia: University of Pennsylvania Press, 2008).

ii Théophile Gautier, Mademoiselle de Maupin (Paris: Charpentier, 1864), p. 26. All subsequent quotations come from this edition.

iii Marquis de Rochegude, Promenades dans toutes les Rues de Paris par arrondissements. 5e Arrondissement (Paris: Librairie Hachette et Cie, 1910), pp. 9, 46.

iv Walter Benjamin, The Arcades Project, ed. R. Tiedemann, trans. H. Eiland and K. McLaughlin (Cambridge, Mass.: Harvard University Press, 1999), p. 460.

v Carlo Ginzburg, 'Clues: Roots of an Evidential Paradigm' in Clues, Myths and the Historical Method, trans. J. and A. Tedeschi (Baltimore and London: John Hopkins University Press, 1992), pp. 96-125, here p. 124.

vi Benjamin, Arcades, p. 460.

vii Ginzburg, 'Clues,' pp. 116-8.

viii Sasha Colby, 'The Literary Archaeologies of Théophile Gautier,' CLCWeb: Comparative Literature and Culture 8.2 (2006): <http://dx.doi.org/10.7771/1481-4374.1310>, p. 2.

ix Michel Foucault, 'Des espaces autres' (conférence au Cercle d'études architecturales, 14 mars 1967), Architecture, Mouvement, Continuité, 5 (1984), pp. 46-49, here p.46.

x Florence Bourillon, 'Changer la ville. La question urbaine au milieu du 19e siècle,' Vingtième Siècle. Revue d'histoire, 64 (1999), pp. 11-23, here pp.12-16.

xi Ginzburg, 'Clues,' p. 101.

xiiThomas Huxley, 'On the Method of Zadig: Retrospective Prophecy as a Function of Science,' in Science and Hebrew Tradition, (New York: D. Appleton and Co., 1896.), pp. 1-23, here pp. 56.

xiiGautier, Mademoiselle de Maupin, p.19. Gautier is not consistent in his aesthetic manifesto for, whereas he famously disavows the utility of art, throughout the Préface and in other writings, he constantly exalts artistic or aesthetic elements in the objects, architecture, and lifestyles of ancient peoples, such as Pompeians in the case of Arria Marcella, the novella discussed in this essay, or Egyptians in the later Roman de la momie.

xiv Théophile Gautier, Arria Marcella, in Récits fantastiques, ed. M. Eigeldinger (Paris: Flammarion, 1981), pp. 237-272, here p. 276. All following quotations from the novella come from this edition.

xv Colby, 'The Literary Archaeologies of Théophile Gautier,' p. 2.

xvi Bourillon, 'Changer la ville,' p.16. 
xvii The most notable attempts to reconfigure the city were made under Rambuteau (1833-1848) and Berger (1848-1853), for example, with the piercing of the first boulevards under the former, and the continuation of the Rue de Rivoli and demolition of the streets around the Louvre and the Hôtel de Ville under the latter, respectively.

xviii Théophile Gautier, 'Paris futur,' in Caprices et Zigzags (Paris: Victor Lecou, 1852), pp. 307-23, here p. 308. All subsequent quotations come from this edition.

xix Ibid.

xx Ibid., p. 314.

xxi See Ruth Fiori, L'invention du vieux Paris: Naissance d'une conscience patrimoniale dans la capitale (Bruxelles: Mardaga, 2012). The historian traces the genesis and evolution of the concept of Le Vieux Paris. The concept takes its place within the history of values, its ethical dimension promoting continuity rather than disruption in relation to architectural principles, historic styles and the urban politics of building (p. 10). Fiori argues for a crystallization of the patrimonial consciousness in the 1880 s, attested by the creation of official bodies specializing in the architectural heritage of Paris; these undertake conservation projects and systematic documentation of specific sites (pp. 24-25). Illustrative of this mature phase is Atget's documentary photography, actively participating in the preservation of urban memory. Still, the sensibility towards the built patrimony and the capital's popular cultures was already developing in Gautier's time, as suggested by the plethora of works devoted to the vanishing city. The debate between demolishing and preserving the urban fabric though divides those concerned about the city's topography from the 1830s into the twentieth century. Gautier supports Haussmann's reliance on heavy demolition.

xxii Bourillon, 'Changer la ville,' p. 14.

xxii Colby, 'The Literary Archaeologies of Théophile Gautier,' p. 2.

xxiv Ibid.

xxv See Charles Marville, Rue des Prêtres Saint-Séverin (de la rue Boutebrie), 1865-1868. Albumen print from collodion-coated glass negative. 30,5 X 26,6 cm. Paris, Musée Carnavalet. (Photo Roger-Viollet). <http://www.parisenimages.fr/fr/galerie-collections/26149-2-ruepretres-saint-severin-rue-boutebrie-paris-veme-arr-photographie-charles-marville-18131879-paris-musee-carnavalet>.

xxvi Charles Lefeuve, Les anciennes maisons de Paris sous Napoléon III. 5 vols. (Paris: A. Faure, 1863-1865), vol. 2, pp. 24-8.

xxvii Le Monde Artiste illustré, 4 December 1898, p. 783. 
xxviii Laure Beaumont-Maillet, 'Atget, novateur ou suiveur?,' in Atget: Une Rétrospective, eds S.

Aubenas and G. Le Gall (Paris: Bibliothèque nationale de France/Hazan 2007), pp. 26-33, here p. 32 .

xxix Eugène Atget, Rue Boutebrie, July 1899, note 298, from the Ecole des beaux-arts collection, ENSBA: 32919, Institut national de l'histoire de l'art, Paris, France.

xxx James Borcoman, Eugène Atget: 1857-1927 (Ottawa: National Gallery of Canada, 1984), p. 66. xxxi Lauren S. Weingarden, 'The Mirror as a Metaphor of Baudelairean Modernity,' in Orientations, Volume 48 of Textxet, eds. C. Clüver, V. B. Plesch and L.H. Hoek (Amsterdam: Rodopi, 2005), pp.17-36, here pp. 28-30.

xxxii Théophile Gautier, 'Une journée à Londres,' Caprices et Zigzags (Paris: Victor Lecou, 1852), pp. 101-140, here p. 113. All subsequent quotations come from this edition. xxxiii Roland Barthes, 'L'effet du réel', Communications, 11 (1968), pp. 84-89, here pp. 87-88. xxxiv The association of Paris with Pompeii is a leitmotif in Gautier's work and subsequently becomes part of a contemporary rhetoric through which present destructions and catastrophes are interpreted in light of past calamities. For the importance of Pompeii as a 'cipher for Parisian fears throughout the century,' see Goran Blix, From Paris to Pompeii, p. 2.

xxxv Stephen Dobson, The Urban Pedagogy of Walter Benjamin: Lessons for the 21st Century. Part 2 (London: Goldsmith Press, Limited, 2002), p. 5.

xxxvi Benjamin, Arcades, p. 473.

xxxvii Homi K. Bhabba, The Location of Culture (New York: Routledge, 1994), p. 245.

xxxviii Timothy Mitchell, 'The Stage of Modernity' in Questions of Modernity, ed. T. Mitchell

(Minneapolis: University of Minnesota Press, 2000), pp.1-34, here p. 23.

xxxix This is the position expressed in 'Paris, Capital of the Nineteenth Century. Exposé of 1935' in Arcades, p. 13. The relationship between commodities and Benjamin's concept of historical awakening through dialectical images is explored by Susan Buck-Morss in The Dialectics of Seeing: Walter Benjamin and the Arcades Project (Cambridge, Mass.: MIT Press, 1991) and Max Pensky in 'Method and Time: Benjamin's Dialectical Images,' in The Cambridge Companion to Walter Benjamin, ed. David S. Ferris (Cambridge: Cambridge University Press, 2004), pp. 177-198.

${ }^{x l}$ Benjamin, Arcades, p. 470. The dialectical image's relationship to time is discussed by Eli Friedlander in 'The Measure of the Contingent: Walter Benjamin’s Dialectical Image,' boundary 2, 35:3 (Duke University Press, 2008), pp. 1-26; DOI 10.1215/01903659-2008010.

xli Foucault, 'Des espaces autres,' pp. 46-49. 
xlii Ibid.

xliii Benjamin, Arcades, p. 470.

xliv Gautier, Arria Marcella, p. 240.

xlv See Foucault, 'Des espaces autres,' pp. 46-49 for a classification of heterotopias.

xlvi See the first Arria Marcella passage quoted above (p. 276).

xlvii Gautier, Mademoiselle de Maupin, p. 35.

xlviii Théophile Gautier, Tableaux de siège: Paris, 1870-1871 (Paris: Charpentier et Cie, 1871). See the chapter 'Une Visite aux ruines. Juin 1871,' pp. 310-347:

Nous étions vingt jours auparavant sur le plateau de Courbevoie, lorsque l'incendie crevant les toits fit explosion dans le ciel comme un volcan, lançant une immense gerbe de fumée où le soleil empêchait d'apercevoir les flammes. Bientôt après, une quantité prodigieuse de papiers brûlés s'abattit sur le sol comme des flocons de neige noire. [...] C'étaient les lapilli de ce Vésuve ouvert au milieu de la ville. (p. 315)

The cataclysmic destruction of Paris is also associated with the experience of empty streets, which a later passage describes thus:

Mais ce qui était particulièrement sinistre, c'était l'aspect de la rue de Lille [...]. Elle apparaissait déserte dans toute sa longueur, comme une rue de Pompéi, sous la lueur livide d'un soleil descendant derrière des brumes chargées de pluie. Les lignés ébréchées des maisons privées de leur toit et de leur couronnement auraient pu faire croire, par l'étendue, la promptitude et la simultanéité du ravage, à l'explosion soudaine d'un volcan. (pp. 322-323)

The insistence on 'l'étendue,' 'la promptitude' and 'la simultanéité' conveys the shocking transformation of the urban landscape from a familiar, living space into a haunted ruin. xlix Pierre Larousse, Grand dictionnaire universel du 19e siècle, 17 vols. (Paris: Administration du grand Dictionnaire universel, 1866-1876), vol. 5, p. 680.

${ }^{1}$ Michel de Certeau, 'Writing vs Time: History and Anthropology in the Works of Lafitau,' trans. J. Hovde, Yale French Studies, 59 (1980), pp. 37-64, here p. 56.

li Foucault, 'Des espaces autres,' pp. 46-49.

lii Ibid.

liii Gautier, Arria Marcella, p. 243.

liv Ibid., p. 254.

lv Ibid., p. 262. 
lvi Ibid., p. 240.

lvii Ibid., p. 239: 'par l'éclat du soleil et la transparence de l'air les objets prennent des couleurs qui semblent fabuleuses dans le Nord, et paraissent appartenir plutôt au monde du rêve.' lviii Ibid., p. 240 - 1.

lix Foucault, 'Des espaces autres,' pp. 46-49.

lx Gautier, 'Une Journée à Londres,' p. 106.

lxi Ibid., p. 114.

lxii Roland Barthes, La chambre claire (Paris: Gallimard, 1980), p. 151.

lxii For a discussion on time travelling in Gautier, see Robert Baudry, 'Gautier voyageur... du temps,' Bulletin de la Société Théophile Gautier, 15.2 (1993), pp. 481-496.

lxiv Christopher Rauschenberg, Paris Changing: Revisiting Eugene Atget's Paris (New York: Princeton Architectural Press, 2007), p. 9.

Ixv Walter Benjamin, Illuminations, trans. H. Zorn (New York: Schocken Books, 1968), p. 255.

lxvi Mark Crinson, 'Photography and the industrial city: Manchester and Salford, ancient and modern,' Word \& Image, 18:1 (2002), pp. 295-314, DOI:

10.1080/02666286.2002.10404831, p. 297.

lxvii Ibid.

Ixviii Thomas Elsaesser, 'Sonnen-Insulaner: On a Berlin Island of Memory', in Memory Culture and the Contemporary City, eds. U. Staiger, H. Steiner, and A. Webber (Basingstoke: Palgrave Macmillan, 2009), pp. 32-51, here p. 38.

lxix Ibid.

lxx Atget often organized his shooting sessions in the morning. See Colin Westerbeck and Joel Meyerowitz, Bystander: A History of Street Photography (Boston: Little Brown, 2001), pp. 105, 110. Although Westerbeck and Meyerowitz ascribe Atget's morning sessions to the technical limitations of his equipment, it could be argued that the shooting interval was equally so a choice, just as he chose to use throughout his career an already old-fashioned large-format camera ( $8 \times 24 \mathrm{~cm}$ view) with glass plates, despite the appearance of the dryplate technique. See Jean-Michel Rabaté, Given: 10 Art 20 Crime: Modernity, Murder and Mass Culture (Eastbourne and Portland, OR: Sussex Academic Press, 2007), pp. 99-100 for Atget's preference for a 'slow-burning camera' (p. 99).

Rumiko Handa, 'Ruins in Sir Walter Scott's Historical Novel: A Case of Diachronic Interpretation of Architecture,' The American Institute of Architects Online Publications (Research, 2011), pp.1-10: <http://www.aia.org/aiaucmp/groups/aia/documents/pdf/aiab087204.pdf>, p. 3. 